\title{
Serum Kisspeptin-10 Levels in Pregnant Women Complicated with Intrauterine Growth Restriction With or Without Preeclampsia
}

\author{
SAMA S. KHALIL, M.D.*; KHALED A. ABULFADLE, M.D.* and WALID M. ELNAGAR, M.D.** \\ The Departments of Physiology* and Obstetrics \& Gynecology**, Faculty of Medicine, Zagazig University, Zagazig, Egypt
}

\begin{abstract}
Background: Placental dysfunction is usually associated with a wide range of obstetric complications. Among the most important of these complications are preeclampsia (PE) and intrauterine growth restriction (IUGR), they are associated with a higher rate of perinatal mortality and morbidity. Kisspeptins are peptide products of the KISS-1 gene, which act through binding with the G-protein coupled receptor 54, Kisspeptin-10 (KP-10) produced by trophoblast cells, has an important role in controlling of migratory features and trophoblastic invasion. Studies that evaluate the role of KP-10 in pregnancy complications are sparse.
\end{abstract}

Aim of the Work: To investigate serum KP-10 levels in correlation with some parameters in pregnancy complicated with IUGR with or without PE.

Subjects and Methods: This study was performed on thirty pregnant woman equally divided into three groups, group I, ten uncomplicated pregnant women with normal blood pressure consider as control, group II, ten preeclamptic women complicated by IUGR and group III, ten normotensive pregnant women complicated by IUGR. The maternal serum was analyzed for KP-10 levels and TNF $\alpha$, while, the maternal urine was analyzed for protein detection. Also, gestational age, fetal birth weight, placental weight, BMI, and MAB were measured.

Results: The present findings revealed significant decrease in maternal serum KP-10 levels in both of group II $(p<0.05)$ and group III $(p<0.01)$ rather than group I. Moreover, KP-10 was positively correlated with fetal birth weight and placental weight in group II and group III, while, negatively correlated with protienuria in group II and TNF $\alpha$ in group II and group III. However, no correlations were found with gestational age, BMI, and mean arterial blood pressure in all groups.

Conclusion: These results propose that the decrease in KP-10 may be responsible for the pathogenesis that underlying the development of IUGR with preeclampsia and normotensive IUGR. So, its measurement might be helpful as a new biomarker in predicting poor placental dysfunction and adverse pregnancy outcome.

Key Words: KP-10, TNF $\alpha$ - Intrauterine growth restriction - Preeclampsia.

Correspondence to: Dr. Sama S. Khalil, Email: haneenmizo@gmail.com

\section{Introduction}

FAILURE of the normal placental function and structure is associated with a wide range of obstetric complications. Among the most important of these complications are preeclampsia and intrauterine growth restriction [1].

Preeclampsia (PE) is defined as the new onset of hypertension and proteinuria after the 20 th gestational week. It affects about $3-10 \%$ of all pregnancies [2].

[3], links PE to a higher risk of perinatal disorders such as intrauterine growth restriction, prematurity and maternal mortality.

Intrauterine growth restriction (IUGR) is a failure of the fetus to reach its genetic growth potential [4], and associates with a higher rate of perinatal mortality and morbidity. Early onset preeclampsia is the major cause of IUGR, but normotensive IUGR with no other apparent causes is not uncommon [5]

The inadequate invasion of uteroplacental arteries causes changes in the placental and fetal circulatory system and may be the cause of the pathological structure and function of the placenta, resulting in impaired transfer of oxygen and nutrients to the fetus, and consequently leading to preeclampsia or intrauterine growth restriction $[6,7]$.

Although the exact mechanism of preeclampsia and IUGR remains complicated and not clear, a number of factors have been concerned, one of them is kisspeptin $[8,7]$

Kisspeptins are peptide products of the KISS1 gene, which act through binding with the Gprotein coupled receptor 54 (GPR54), also known 
as the KISS-1 receptor. The initial protein product of the KISS- 1 gene is a 145 -amino-acid peptide, which is cleaved into shorter, biologically active products known as KP-54, KP-14, KP-13, and KP$10[\mathbf{9 , 1 0}]$.

KP-10 was reported to has a role in gynecological endocrine function which apparent at the onset of puberty due to stimulating hypothalamic Gonadotropin-Releasing Hormone (GnRH) release, as both $\mathrm{GnRH}$ and KP-10 have roles in placentation, regulation of reproduction, pregnancy and cardiovascular function $[\mathbf{9 , 1 1}]$

Also, KP-10 and GPR54 produced by trophoblast cells, have an important role in controlling of migratory features and trophoblastic invasion [12]

Several studies were done to determine the role of KP-10 during pregnancy complications and if it can be used as a biomarker for placental dysfunction, however, the results of those studies are controversial.

The aim of the work is to investigate maternal serum level of KP-10 in correlation with some clinical and biochemical parameters in case of pregnant women complicated with IUGR with or without PE.

\section{Subjects and Methods}

This study was conducted in the period from July to October 2017 in the Faculty of Medicine, Zagazig University. Written consent was taken from all ladies before the study. A total of 30 pregnant women were included in this study.

\section{Population inclusion criteria}

- Age between 18-42 years.

- Gestational age between 34-38 weeks, singlton pregnancy.

- Only cases delivered by caesarean section were included in the study to avoid the placental oxidative stress reported in normal delivery [13].

\section{Exclusion criteria}

- Cases complicated with spontaneous abortion, stillbirth and chromosomal abnormalities.

- History of maternal illness such as hypertension, gestational diabetes mellitus, renal, hepatic, cardiac, or autoimmune disorders.

\section{Groups:}

Group I: Represents the control group including 10 pregnant women with normal blood pressure, blood glucose level, normal clinical examination and fetal birth weight above the 10th percentile. Birth weight percentiles were determined according to growth curves explored by ultrasonographic measurement when the weight of the fetus was lower than expected in relation to the gestational age $[14,15]$

Group II: Represent preeclamptic women complicated with the intrauterine growth restricted fetuses (PE-IUGR), the group comprised 10 patients with the fetal birth weight below the 10th percentile according to growth curves $[\mathbf{1 4}, \mathbf{1 5}]$. In addition, this diagnosis was confirmed by the infant's weight at birth according to the [16]. Preeclampsia was diagnosed by the increased blood pressure of $>140$ $\mathrm{mmHg}$ systolic and $>90 \mathrm{mmHg}$ diastolic in women who were normotensive before 20 weeks of gestation and accompanied by proteinuria, more than $0.3 \mathrm{~g}$ protein in $24 \mathrm{~h}$ urine specimen.

Group III: Represents the normotensive pregnant women with intrauterine growth restricted fetuses (IUGR), the group comprised 10 patients with the fetal birth weight below the $10^{\text {th }}$ percentile according to growth curves $[\mathbf{1 4 , 1 5}]$. All subjects were delivered by caesarean section in the Gynecology and Obstetrics Department, Zagazig University Hospitals.

\section{Anthropometric measurements:}

- Body mass index (BMI) for all the subjects body weight and height were measured then BMI calculated according to the following equation $(\mathrm{kg} / \mathrm{m} 2)$ : A person's weight represented in kilograms divided by the square of height in meter.

- Placental weight was measured according to a standard protocol [17].

- Fetal birth weight was measured to the nearest $100 \mathrm{~g}$ using beam balance scales, with the infant lightly clothed [18]

\section{Blood pressure measurements :}

Blood pressure was measured using a mercury sphygmomanometer according to the recommendations of the British Hypertension Society [19] MAP ( $\mathrm{mmHg}$ ) was calculated according to the equation:

MAP $=[$ Systolic pressure $+(2 \times$ Diastolic pressure $)] / 3$.

\section{Blood sampling:}

$5 \mathrm{ml}$ blood was taken from the mothers for assessment of studied parameters, the clotted blood 
was centrifuged at $2.500 \mathrm{rpm}$ for $15 \mathrm{~min}$ and the sera were stored at $-80^{\circ} \mathrm{C}$ until used for analysis.

\section{laboratory Investigations:}

- Serum KP-10 levels, were estimated using an ELISA commercially available kit according to the manufacturer's instructions (Life Span Bio Sciences).

- Tumor necrosis factor alpha (TNF $\alpha$ ), serum protein was detected by human enzyme-linked immunosorbent assay (RAB0476) from NORGEN BIOTEC- Co. (Emirates Tower, Hamdan Street, Abu Dhabi, UAE). according to the manufacturer's instructions

- Proteinuria (24h urine collection), all subjects were asked to collect the urine from $5 \mathrm{pm}$ to the next $5 \mathrm{pm}$ in graduated container and remind at room temperature for total protein analysis, using, total protein, Micro Kit (ProteoSpin, Cat. 17400) using kits supplied by NORGEN BIOTEC-Co., according to [20]

\section{Statistical analysis:}

The results of this study were expressed as mean \pm standard deviation (SD) and were statistically analyzed with the computer program, the Statistical Package for the Social Sciences (SPSS), version 18 (SPSS Inc., Chicago, IL, United States). The Analysis of Variance (ANOVA) followed up with post hoc test were applied to compare the differences among means of three independent groups. Pearson's correlation analysis was performed to screen potential relations between serum levels of KP-10 and all measured parameters. For all statistical tests done, $p$-value $<0.05$ was considered to be statistically significant.

\section{Results}

Both of PE-IUGR and normotensive with IUGR groups showed significant decreases in the mean values \pm SD of serum KP-10 levels, gestational age, fetal birth weight, and placental weight in comparison to normotensive control group.

There were no statistically significant differences in serum KP-10 and fetal birth weight in normotensive with IUGR and PE-IUGR group, while there were a differences in the mean values \pm SD of gestational age and placental weight.

Further, there was no statistically significant differences in the mean values \pm SD of BMI of PE- IUGR and normotensive with IUGR groups rather than control group.

PE-IUGR group showed significant increases in the mean values \pm SD of protienuria, systolic, diastolic and mean arterial blood pressures Vs. control and normotensive-IUGR groups, however not differences was found in normotencive-IUGR as compared to control.

Moreover, serum TNF $\alpha$ was significantly increased in PE-IUGR and normotensive-IUGR in comparison to control and also statically differences were found between groups (Table 1).

Table (1): Analysis of study parameters(mean $\pm \mathrm{SD}$ ) between the study groups and the control group.

\begin{tabular}{|c|c|c|c|}
\hline $\begin{array}{ll} & \text { Groups } \\
\text { Parameters } & \end{array}$ & Control & PE-IUGR & Normotensive -IUGR \\
\hline Kisspeptin-10 level (ng|ml) & $2.9 \pm 0.6$ & $1.64 \pm 0.4 p<0.05^{\mathrm{a}}$ & $1.63 \pm 0.3 p<0.01 \mathbf{a} \& \mathrm{NS}^{\mathbf{b}}$ \\
\hline Gestational age (weeks) & $37.5 \pm 1.08$ & $34 \pm 0.8 p<0.001$ a & $35.2 \pm 0.7 p<0.05 \mathbf{a}, \mathbf{b}$ \\
\hline Fetal birth weight (kg) & $3.3 \pm 0.11$ & $2.18 \pm 0.22 p<0.001 \mathrm{a}$ & $2.28 \pm 0.35 p<0.001^{\mathbf{a}} \& \mathrm{NS}^{\mathbf{b}}$ \\
\hline Placental weight (g) & $482.5 \pm 22.8$ & $385.5 \pm 22.5 p<0.001^{\mathrm{a}}$ & $320.4 \pm 33.6 p<0.001 \mathbf{a}, \mathbf{b}$ \\
\hline $\mathrm{BMI}\left(\mathrm{Kg} / \mathrm{m}^{2}\right)$ & $23.36 \pm 2.7$ & $25.2 \pm 3.7 \mathrm{NS} \mathbf{a}$ & $23.6 \pm 3.6 \mathrm{NS} \mathbf{a}, \mathbf{b}$ \\
\hline Protienuria $(g / 24 h)$ & $0.046 \pm 0.016$ & $1.64 \pm 0.74 p<0.001 \mathrm{a}$ & $0.049 \pm 0.02 \mathrm{NS}^{\mathbf{a}} \& p<0.001 \mathbf{b}$ \\
\hline Systolic blood pressure $(\mathrm{mmHg})$ & $120.2 \pm 4.46$ & $147.9 \pm 9.8 p<0.001 \mathrm{a}$ & $118.9 \pm 3 \mathrm{NS} \mathbf{a} \& p<0.001 \mathbf{b}$ \\
\hline Diastolic blood pressure $(\mathrm{mmHg})$ & $75.8 \pm 3.7$ & $99.1 \pm 5.7 p<0.001^{\mathrm{a}}$ & $79.3 \pm 5.1 \mathrm{NS}^{\mathbf{a}} \& p<0.001^{\mathbf{b}}$ \\
\hline MAP (mmHg) & $90.5 \pm 2.8$ & $114.2 \pm 5.3 p<0.05^{\mathrm{a}}$ & $92.3 \pm 3.8 \mathrm{NS}^{\mathbf{a}} \& p<0.001^{\mathbf{b}}$ \\
\hline $\mathrm{TNF} \alpha(\mathrm{pg} / \mathrm{mL})$ & $78.9 \pm 11.9$ & $350.2 \pm 29.7 p<0.001^{\mathrm{a}}$ & $307.8 \pm 22.5 p<\mathrm{S} 0.001$ a, b \\
\hline
\end{tabular}

$\mathbf{a}=p$-value of significance versus control. $\quad \mathbf{b}=p$-value of significance versus PE-IUGR group. NS = Non-significance 
Serum KP-10 levels in normal control group were positively correlated to gestational age while they showed non-significant correlations with fetal birth weight, placental weight, BMI, protienuria, MAP and TNF $\alpha$. Also, in PE-IUGR group serum KP-10 levels were positively correlated to fetal birth weight and placental weight, and negatively correlated to protienuria and TNF $\alpha$. While, they showed non-significant correlations with gestational age, BMI and MAP.

Moreover, serum KP-10 levels in normotensiveIUGR group were positively correlated to fetal birth weight and placental weight, and negatively correlated to TNF $\alpha$. While, they showed nonsignificant correlations with gestational age, BMI, protienuria and MAP (Table 2).

Table (2): Pearson's correlation analysis between serum KP-10(ng $\mid \mathrm{ml})$ levels and all parameters in the studied groups.

\begin{tabular}{llcccccc}
\hline & \multicolumn{2}{c}{ Control } & \multicolumn{2}{c}{ PE-IUGR } & \multicolumn{2}{c}{$\begin{array}{c}\text { Normotensive- } \\
\text { IUGR }\end{array}$} \\
\cline { 2 - 8 } & \multicolumn{1}{c}{$r$} & $p$-value & $r$ & $p$-value & $r$ & $p$-value \\
\hline Gestational age (weeks) & 0.64 & $0.04^{*}$ & 0.06 & 0.8 & -0.4 & 0.2 \\
Fetal birth weight (kg) & 0.006 & 0.9 & 0.748 & $0.01^{*}$ & 0.67 & $0.03^{*}$ \\
Placental weight (g) & 0.29 & 0.4 & 0.755 & $0.01^{*}$ & 0.69 & $0.02^{*}$ \\
BMI (Kg/m $\left.{ }^{2}\right)$ & 0.41 & 0.2 & 0.39 & 0.2 & 0.16 & 0.6 \\
Protienuria (g/24h) & 0.01 & 0.9 & -0.65 & $0.03^{*}$ & 0.26 & 0.4 \\
MAP (mmHg) & 0.34 & 0.3 & 0.01 & 0.9 & 0.2 & 0.4 \\
TNF $\alpha(\mathrm{pg} / \mathrm{ml})$ & 0.47 & 0.16 & -0.67 & $0.03^{*}$ & -0.72 & $0.01^{*}$ \\
\hline$r=$ Correlation with KP-10. & \multicolumn{2}{c}{$*$ Significance. } & NS = Non-significant. & &
\end{tabular}

\section{Discussion}

The pregnancy to be succeed requires the cooperation between the developing trophoblasts by its invasive ability and receptive uterine tissue, depending on a regulatory factors that affect the biological behavior of trophoblasts [21].

It was reported that normal placental function depends on the accurate expression of kisspeptin and its receptors [22].

Plasma KP-10 levels in non pregnant females are thought to be low. However, the concentration of it increases during pregnancy, reaching a maximal level in late pregnancy [23], the placenta is believed to be the source of this elevation, because $\mathrm{KP}-10$ returns to non pregnant levels immediately after birth. Also, the expression of kisspeptin and GPR-54 had previously been reported in human trophoblasts $[10,24,25]$, and placenta [26,27]

The results of this study revealed significant decrease in levels of maternal serum KP-10 in both of PE-IUGR and normotensive women with intrauterine growth restriction groups in comparison with the normal pregnant control.

The present results were in agreement with $[22,26,28]$, who reported that circulating Kp-10 levels decreased in pregnancies complicated with severe preeclampsia and IUGR as a result of poor placentation.

Also, several studies revealed the same findings of a decrease serum Kp-10 levels in early and late pregnancy in women who subsequently developed PE with IUGR or normotensive women with IUGR [29-32]

Furthermore, [33] reported that serum kisspeptin10 levels in preeclampsia were significantly lower than those in healthy pregnancies despite higher placental kisspeptin expression which a combined with lower matrix-metalloproteinases (MMP-2) and (MMP-9) mRNA, and protein expression in trophoblasts.

However, [34] reported that, despite mRNA and protein expressions faced each other, it is important to consider that altered expression does not necessarily associate with altered function.

The mechanism by which KP-10 is decreased in pregnancies complicated with $\mathrm{PE}$ or developed IUGR still undetermined, it was postulated that $\mathrm{KP}-10$ level is involved in fine-tuning of placental invasion, as high level of KP-10 inhibit extensive endovascular invasion and a low expression of this peptide would signal low invasive capacity. Thus, development of smaller, shallow placentas occurs 
first, and these produce less amount of KP-10 in maternal circulation $[31,35]$. Also, releasing of KP10 during pregnancy is related to the size of the placenta [10].

So the decrease in circulating KP-10 levels may be the result rather than the cause of IUGR and PE.

However, [36] didn't find any significant difference in circulating KP-10 levels between patients with PE complicated with IUGR and normotensive controls in late pregnancy. Also, different to the present data $[27,37,38]$, showed that plasma kisspeptin levels were significantly increased in pregnancy complicated with IUGR and sever preeclampsia from the second trimester to the third trimester than normal pregnancy.

The discrepancy of the present findings from previous studies may be due to the low number of women participated or time staging of pregnancy.

Normal pregnancy is accompanied by elevation of pro-inflammatory cytokines such as tumor necrosis factor $\alpha$ (TNF $\alpha)$ and IL6 [39], although such elevation is more increased in PE and complicated pregnancies with IUGR [40].

Macrophages generate and respond to a wide variety of cytokines and may be concerned in decidual paracrine networks that control trophoblast invasion $[41,42]$.

Activated macrophages produce high levels of $\mathrm{TNF} \alpha$ [42]. One of the equivalent receptors of TNF $\alpha$, TNF receptor 1 (TNF-R1), is expressed by trophoblast cells [43], activated macrophages provoke trophoblast apoptosis by secretion of TNF $\alpha$ that binds to the trophoblastic TNF-R1.

Also in recent study explored by [44], which reported that abnormal elevation of TNF- $\alpha$ affect GnRH neuron function by interfering with KISS1R expression and impairing kisspeptin signaling and function.

However, KP-10 accelerates the inflammatory state and increase monocyte adhesion in endothelial cells and macrophage foam cell formation [45]

Regarding correlation, the current study found that serum KP-10 levels were significantly correlated with gestational age in control group rather than other groups. Although, there were no correlations with fetal birth weight, placental weight, proteinuria, BMI, MAP and TNF $\alpha$. The results presented by [32], showed that circulating KP-10 levels were correlated positively with gestational weeks in normotensive pregnant women.

Moreover, this study has been found that, reduced serum KP-10 levels were significantly correlated with fetal birth weight and placental weight, but were negatively correlated with $\operatorname{TNF} \alpha$ and protienuria. While there were no correlation with $\mathrm{BMI}$ or MAP in PE-IUGR group rather than control group.

These results were supported by $[\mathbf{3 1}, \mathbf{3 2}, \mathbf{4 5}]$, who demonstrated that reduced KP-10 levels were significantly associated with fetal and placental weights in PE patients complicated by IUGR, while negatively associated with $\operatorname{TNF} \alpha$.

$[\mathbf{4 6 , 4 7 ]}$ had been found that circulating KP-10 levels were negatively correlated with protein in urine in preeclampsia rather than control and [36], observed no correlation between KP-10 levels in the third-trimester of pregnancy and blood pressure in preeclamptic patients with IUGR.

Different results were presented by $[\mathbf{3 0 , 4 6 ]}$, who reported that serum KP-10 levels were inversely correlated with blood pressure in complicated preeclampsia with IUGR rather than control. While, [48], showed a positive correlation between circulating KP-10 levels and systolic blood pressure in preeclamptic patients and explained that by the vasoactivities property of KP-10, which leads to generalized maternal endothelial dysfunction.

Collected data about correlations of circulating KP-10 with clinical, biochemical parameters and placental dysfunctional parameters was limited in normotensive pregnant women complicated by IUGR. In the present findings, reduced serum KP10 levels were significantly correlated with fetal birth weight and placental weight, and were negatively correlated with TNF $\alpha$. Whilst there were no correlation with BMI or MAP in normotensiv pregnant with IUGR group rather than control group.

The same findings explored by [32], serum KP10 levels correlated significantly with fetal birth weight and placental weight in normotensive with IUGR rather than control group.

While, [29], reported that there were no significant correlations between serum KP-10 levels and fetal birth weight.

\section{Conclusion:}

This study revealed that serum KP-10 levels are decreased in PE-IUGR and normotensive - 
IUGR groups and correlated positively with fetal and placental weights, so, its measurement might be helpful as a new biomarker in predicting poor placental dysfunction and adverse pregnancy outcome. Further studies are required to give explain the molecular basis on relationship under this.

\section{References}

1- SOBER S., REIMAN M., KIKAS T., RULL K., INNO R and VAAS P.: Extensive shift in placental transcriptome profile in preeclampsia and placental origin of adverse pregnancy outcomes. Sci. Rep., 5: 1333 6, 2015.

2- FABRY I., RICHART T., CHENG X., VAN BORTEL L. and STAESSEN J.: "Diagnosis and treatment of hypertensive disorders during pregnancy." Acta. Clinica. Belgica., 65 (4): 229-236, 2010.

3- YOUNG B., LEVINE R. and KARUMANCHI S. : "Pathogenesis of preeclampsia." Annual Review of Pathological Mechanical Disease, 5: 173-192, 2010.

4- BURTON G., YUNG H.W., CINDROVA-DAVIES T. and CHARNOCK-JONES D.: Placental endoplasmic reticulum stress and oxidative stress in the pathophysiology of unexplained intrauterine growth restriction and early onset preeclampsia. Placenta., 30: 43-48. 2009.

5- MANDRUZZATO G., ANTSAKLIS A., BOTET F., CHERVENAK F., FIGUERAS F., GRUNEBAUM A. and PUERTO B.: Intrauterine restriction (IUGR). Journal of Perinatal Medicine, 36: 277-281, 2008.

6- SIBAI B., DEKKER G. and KUPFERMINC M.: Preeclampsia. Lancet., 365: 785-799, 2005

7- SEN A., KUSHNIR V.A., BARAD D.H. and GLEICHER N.: Endocrine autoimmune diseases and female infertility. Nat. Rev. Endocrinol., 10: 37-50, 2014.

8- AETKOVIA A., MILJIC D., LJUBIA M., PATTERSON M., GHATEI J., STAMENKOVIA M., NIKOLICDJUROVIC S. and DOKNIC M.: "Plasma kisspeptin levels in pregnancies with diabetes and hypertensive disease as a potential marker of placental dysfunction and adverse perinatal outcome." Endocrine. Research, 37 (2): 78-88, 2012.

9- DUNGAN H., CLIFTON D., and STEINER R: "Minireview: kisspeptin neurons as central processors in the regulation of gonadotropin releasing hormone secretion." Endocrinology, 147 (3): 1154-1158, 2006.

10- PARK D.W., LEE W.S., HONG S.R., HAN A.R., KWAK KIM J. and K.M. YANG K.M.: "Expression of Kisspeptin and its receptor GPR54 in the first trimester trophoblast of women with recurrent pregnancy loss." American Journal of Reproductive Immunology, 67 (2): 132-13 9, 2012.

11-MEAD E.J., MAGUIRE J.J., KUC R.E. and DAVENPORT A.P. : Kisspeptins Are Novel Potent Vasoconstrictors in Humans, with a Discrete Localization of Their Receptor, G Protein-Coupled Receptor 54, to Atherosclerosis-Prone Vessels. Endocrinology, 148: 140-147, 2007.

12- BABA T. , KANG H., HOSOE Y., KHARMA R., ABIKO K., MATSUMURA N. and HAMANISHI J.: "Menstrual cyclic change of metastin/GPR54 in endometrium." Medical Molecular Morphology, 1-9, 2014.
13- SOLBERG R., PERRONE S., SAUGSTAD O.D. and BUONOCORE G.: Risks and benefits of oxygen in the delivery room. J. Matern. Fetal. Neonatal. Med., 25 (1): 41-44, 2012

14- ALEXANDER G.R., KOGAN M., MARTIN J. and PAPIERNICK E.: What are the fetal growth patterns of singletons, twins and triples in United States. Clin. Obstet. Gynecol., 41 (1): 114-125, 1998.

15- RESNIK R: Intrauterine growth restriction. Obstet. Gynecol., 99 (3): 490-6, 2002.

16- BRETELLE F., SABATIER F., BLANN A., D'ERCOLE, BOUTIERE B., MUTIN M. and BOUBLI L.: Maternal endothelial soluble cell adhesion molecules with isolated small for gestational age fetuses, comparison with preeclampsia. British Journal of Ob-stetrics Gynaecology, 108: 1277-1282, 2001.

17- PINAR H., SUNG C.J., OYER C.E. and SINGER D.B.: Reference values for singleton and twin placental weights. Pediatr. Pathol. Lab. Med., 16 (6): 901-7. Placenta, 11 : 467-475, 1996.

18- MOORE V., MILLER A., BOULTON T., COCKINGTON R., HAMILTON CRAIG I., MAGAREY A., and ROBINSON J.: Placental weight, birth measurements, and blood pressure at age 8 years Archives of Disease in Childhood, 74: 538-541, 1996.

19- PETRIE J.C., O'BRIEN E.T., LITTLER W.A. and DE SWIET M.: Recommendations on blood pressure measurement. Br. Med. J. (Clin. Res. Ed.), 293: 611-615, 1986.

20- BRADFORD M.M: A refined and sensitive method for the quantitation of microgram quantities of protein utilizing the principle of protein-dye binding. Analyt. Biochem., 72- 24, 1976.

21- LI L., TIAN J., ZHOU L., WU S., ZHANG S., QI L. and ZHANG H.: Role of kisspeptin/GPR54 in the first trimester trophoblast of women with a history of recurrent spontaneous abortion .Int. J. Clin. Exp. Pathol., 10 (8): 8161$8173,2017$.

22- SMETS E.M., DEURLOO K.L., GO A.T., VAN VUGT J.M., BLANKENSTEIN M.A. and OUDEJANS C.B.: Decreased plasma levels of metastin in early pregnancy are associated with small for gestational age neonates. Prenat. Diagn., 28: 299-303, 2008.

23- HORIKOSHI Y., MATSUMOTO H., TAKATSU Y., OHTAKI T. and KITADA C.: Dramatic Elevation of Plasma Metastin Concentrations in Human Pregnancy: Metastin as a Novel Placenta-Derived Hormone in Humans. J. Clin. Endocrinol. Metab., 88: 914-919, 2003.

24- BILBAN M., GHAFFARI-TABRIZI N., HINTERMANN E, BAUER S., MOLZER S., and ZORATTI C.: Kisspeptin-10, a KiSS-1/metastin-derived decapeptide, is a physiological invasion inhibitor of primary human trophoblasts. J. Cell. Sci., 117 (13): 19-28, 2004.

25- QIAO C., CHENG D.L., ZHANG S.L., WANG C.H. and LIN Q.D.: [The role of KiSS- 1 and matrix metalloproteinase-9 in regulation of invasion of trophoblasts]. Zhonghua Yi Xue Za Zhi, 85: 839-42, 2005.

26- CARTWRIGHT J.E. and WILLIAMS P.J: Altered placental expression of kisspeptin and its receptor in pre-eclampsia. Journal of Endocrinology, 214: 79-85, 2012. 
27- QIAO C., WANG C., ZHAOJ, LIU C. and SHANG T.: Elevated Expression of KiSS-1 in Placenta of Chinese Women with Early-Onset Preeclampsia. PLoS. ONE., 7 (11): 48937, 2012.

28- ZIYARAA M.A., HAMDAN F.B. and MOUSA L.R.: Correlation of Kisspeptin-10 level and fetal well-being in preeclamptic patients. Taiwan J. Obstet. Gynecol., 55: 840-846, 2016.

29- ARMSTRONG R.A., REYNOLDS R.M., LEASK R., SHEARING C.H., CALDER A.A. and RILEY S.C.: Decreased serum levels of kisspeptin in early pregnancy are associated with intra-uterine growth restriction and pre-eclampsia. Prenat. Diagn., 29: 982-985, 2009.

30- LOGIE J.J., DENISON F.C., RILEY S.C., RAMAESH T., FORBES S., NORMAN J.E. and REYNOLDS R.M.: Evaluation of kisspeptin levels in obese pregnancy as a biomarker for pre-eclampsia. Clinical Endocrinology, 76: 887-893, 2011.

31- CETKOVIC A., MILJIC D., LJUBIC A., PATTERSON M., GHATEI M. and STAMENKOVI C.: Plasma kisspeptin levels in pregnancies with diabetes and hypertensive disease as a potential marker of placental dysfunction and adverse perinatal outcome. Endocr. Res., 37: 78-88, 2012.

32- KAVVASOGLU S., OZKAN Z., KUMBAK B., SIMSEK $M$ and ILHAN N.: Association of kisspeptin-10 levels with abortus imminens: A preliminary study. Arch. Gynecol. Obstet., 285: 649-653, 2012.

33- MATJILA M., MILLAR R., VAN DER SPUY Z. and KATZ A.: Elevated placental expression at the maternalfetal interface but diminished maternal circulatory kisspeptin in preeclamptic pregnancies. Pregnancy Hypertens, 6: 79-87, 2016.

34- TURNER J.A.: Diagnosis and management of preeclampsia: an update. International Journal of Women's Health., 2: 327-337, 2010.

35- REYNOLDS R.M., LOGIE J.J., ROSEWEIR A.K., MCKNIGHT A.J. and MILLAR R.P.: A role for kisspeptins in pregnancy: Facts and speculations. Reproduction, 138: $1-7,2009$.

36- NIJHER G.M., CHAUDHRI O.B., RAMACHANDRAN R., MURPHY K.G., ZAC-VARGHESE S.E. and FOWLER A.: The effects of kisspeptin-54 on blood pressure in humans and plasma kisspeptin concentrations in hypertensive diseases of pregnancy. Br. J. Clin. Pharmacol. 70: 674-81, 2010

37- ZHANG H., LONG Q., LINGL, GAO A., LI H. and LIN Q.: "Elevated expression of KiSS-1 in placenta of preeclampsia and its effect on trophoblast." Reproductive biology, 11 (2): 99-115, 2011.
38- SCHAFER S., AY S. S., KAYA D., SOZMEN M., BECERIKLISOY H.B. and GAOGLU A.R.: Kisspeptin-10 and the $\mathrm{G}$ protein-coupled receptor 54 are differentially expressed in the canine pregnant uterus and trophoblast cells. Reprod Domest Anim., 52 (2): 123-129, 2017.

39- LUPPI P., HALUSZCZAK C., TRUCCO M. and DELOIA J.A.: Normal pregnancy is associated with peripheral leukocyte activation. Am. J. Reprod. Immunol., 47: 7281, 2002.

40- SACKS G.P., STUDENA K., SARGENT I.L. and REDMAN C.W.: Normal pregnancy and preeclampsia both produce inflammatory changes in peripheral blood leukocytes akin to those of sepsis. Am. J. Obstet. Gynecol., 179: 80-86, 1998 .

41- HUNT JS: The role of macrophages in the uterine response to pregnancy. Placenta., 11: 467-475, 1990.

42- BENYO D.F., SMARASON A., REDMAN C.W.G., SIMS C. and CONRAD K.P.: Expression of inflammatory cytokines in placentas from women with preeclampsia. J. Clin. Endocrinol. Metab., 86 (6): 2505-12, 2001.

43- YUI J., HEMMINGS D., GARCIA LLORET M.I. and GUILBERT L.J.: Expression of the human p55 and p75 tumor necrosis factor receptors in primary villous trophoblasts and their role in cytotoxic signal transduction. Biol. Reprod., 55: 400-409.

44- SARCHIELLI E., COMEGLIO P., SQUECCO R., BALLERINI L., MELLO T. and MORELLI: A Tumor Necrosis Factor-6c Impairs Kisspeptin Signaling in Human Gonadotropin-Releasing Hormone Primary Neurons. Clin. Endocrinol. Metab., 102 (1): 46-56, 2017.

45- SATO K., SHIRAI R., YAMASHITA T., YOSHIZAWA H., WATANABE R., and MATSUYAMA T.: A potent vasoconstrictor Kisspeptin-10 accelerates atherosclerosis: amelioration by its receptor GPR54 antagonist. European Heart Journal., 38: 501-P679. 2017.

46- ADALI E., KURDOGLU Z., KURDOGLU M., KAMACI M., KOLUSARI A. and YILDIZHAN R.: Metastin levels in pregnancies complicated by pre-eclampsia and their relation with disease severity. Journal of Maternal, Fetal \& Neonatal Medicine, 25 (12): 2671-2675, 2012.

47- ZIYARAA A.M., HAMDANB A.F. and MOUSAC A.L.: Kisspeptin-10 level in preeclamptic pregnant women. Journal of Obstetrics \& Gynecology and Reproductive Biology. Photon., 115: 203-212, 2014.

48- WAUGH J.J. and SMITH M.C.: Hypertensive Disorders In: Edmonds DK (ed). Dewhurst's Textbook of Obstetrics \& Gynaecology. $8^{\text {th }}$ edition. UK. Wiley Blackwell., 101110,2012 


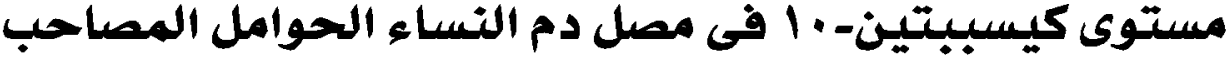

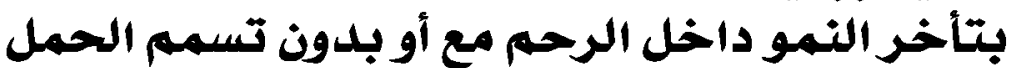

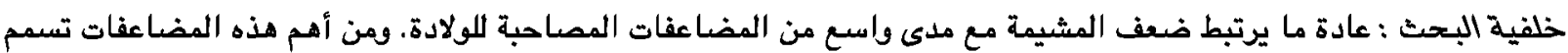

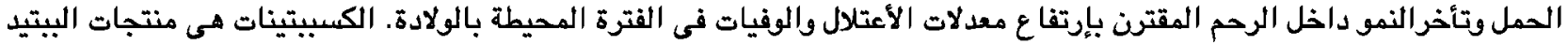

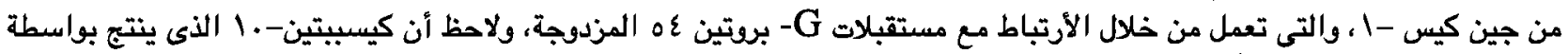

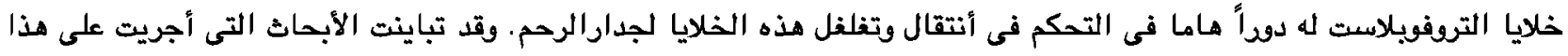

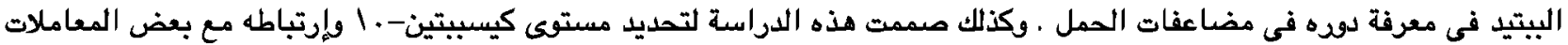

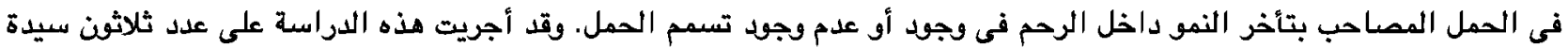
حامل وقسمت إلى ثلاث مجموعات متساوية: الهجموعة الأولى : الضابطة، تشمل عدد عشرة نساء الحوامل بدوف مضاعفات مع معدل طبيعى لضغط الدم. المجموعة الثانية: تشمل عدد عثرة نساء الحوامل لديهم تسمم حمل ومصاحب بتأخر فى النمو داخل الرحم . الهجمهوعة الثالثة: تشمل عدد عشرة نساء الحوامل ذات ضغط الدم الطبيعى مصاحب لتأخر في النمو داخل الرحم ، تم تحليل

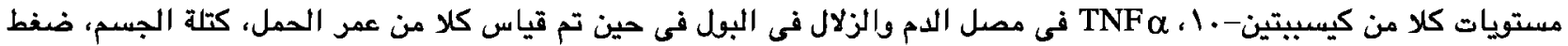

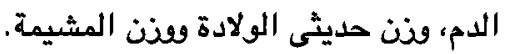

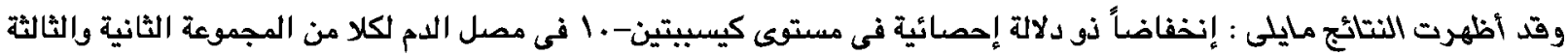

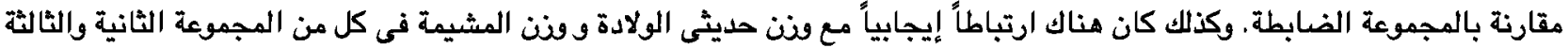

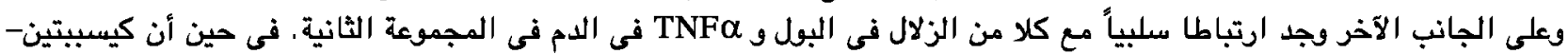

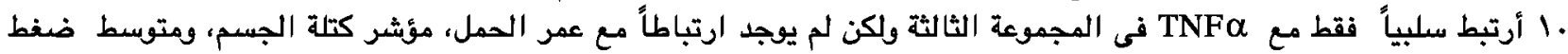
الدم الشريانى.

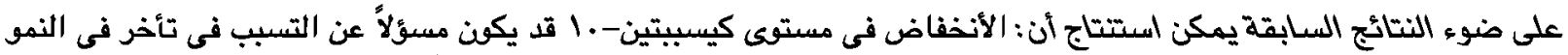

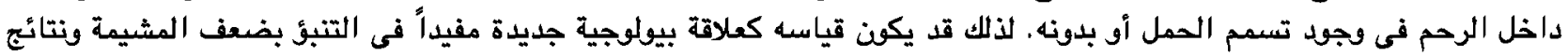

